International Review of Research in Open and Distributed Learning Volume 19, Number 4

\title{
Effect of Communication Management on Distance Learners' Cognitive Engagement in Malaysian Institutions of Higher Learning
}

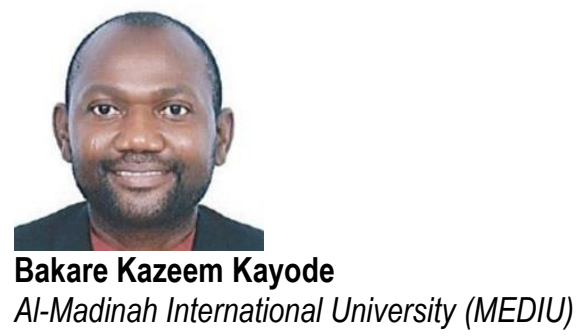

\begin{abstract}
Rapid development of communication tools has brought about contentious issues in communication management in distance learning (DL) programs. The aim of this study is to investigate the relationships between communication management indicators, namely, communication practices, communication tools, and students' cognitive engagement in distance learning programs. A conceptual framework for communication management was developed from Moore's Transactional Distance Learning Theory (TDLT) and other existing literature. This study was conducted using quantitative research design. A questionnaire (a survey method) was used to elicit responses from 450 randomly selected in-service teachers from three Malaysian Public universities that offer blended mode distance-learning programs. Data analysis was conducted using Analysis of Moment Structures (AMOS) software to test the structural path of communication practices, communication tools, and students' cognitive engagement. Tests of hypotheses provided evidence of measures of fit statistics. The findings provide evidences that effective communication practices and communication tools have strong positive influence on distance students' cognitive engagement.
\end{abstract}

Keywords: communication management, cognitive engagement, communication practices, communication tools, distance learners 


\section{Introduction}

Distance education or distance learning is a field of education that focuses on the use of technology in the delivery of curriculum to students who are not physically on site to receive their education (Taylor, 2006). Teaching and learning at a distance can be delivered via full electronic learning otherwise known as single delivery mode programs (synchronous or asynchronous) or blended delivery mode programs (Singh, 2003). Advancement in technology and the Internet has made the medium of teaching and learning more interactive and dynamic at a distance (Khan, 2005; Swerling \& Thorson, 2014). Communication plays a very important role in the success of distance education programs. Guffey (2008) defines communication as a process within which the sender has an idea, encodes it as a message, and sends it over a channel (faceto-face, e-mail, telephone, or other methods of transmitting). The recipient then decodes this message (Guffey, 2008). This definition clearly shows the link between 'teaching-learning' and 'communication,' as teachers constantly impart new knowledge (or transmit information) and students receive this knowledge. The need to expand education via distance learning was given priority in the Tenth Malaysian Plan (20152025). It is stated in the plan that students will benefit from robust cyber infrastructure that can support the use of technologies like videoconferencing, live streaming and Massive Open. Higher learning institutions will also be required to ensure that $70 \%$ of their programmes use blended learning models.

The Malaysian Ministry of Higher Education (MOHE) encourages primary and secondary school teachers to upgrade their knowledge, skills, and qualifications (MoHE 2011-2015). To do this, Malaysian government made it compulsory for all teachers with a diploma degree who are still working (in-service teachers) in both primary and secondary school to complete a bachelor's degree through blended mode distance education programs offered by selected public universities (MoHE 2011-2015). This program, known as Program Pensiswazahan Guru (PPG), further guarantees the proposed shift of teacher education in Malaysia from quantitative expansion to qualitative improvement, and this shift will continue to respond successfully to the changes and challenges of the future (Noraini, 2010).

Ironically, the instructional support in distance education programs has not been put in proper perspectives (Mei, Su Ahmad and Rosnain 2017). This occurred because most institutions have not fully embraced distance education (Sa'adon, Dahlan, \& Zainal, 2013). Such institutions offer distance learning as a crafted program. In these settings, the perception is that the instructor's role is mainly to grade or mark students' assignments, which are completed at an appointed time (Lentell, 2003). As the need for quality materials that can improve student cognitive engagement in distance education become imperative, distance-learning instructors must acquire requisite experience in Open Distance Learning (ODL) (Sa'adon, Dahlan, \& Zainal, 2013; Rajasegeran, 2012). The recruitment and selection of instructors with less experience in teaching distance-learning programs in most institutions is superfluous (Khan, 2005; Moore \& Kearsely, 2005).

Maintaining quality pedagogy and efficient use of communication platforms in distance learning programs are the major challenges to many higher institutions (Allen \& Seaman, 2013; Swerling \& Thorson, 2014). Studies in Malaysia revealed that many distance education tutors did not support distance students with necessary pedagogical practices such as higher-order thinking and collaborative learning (Bahroom \& Abdol Latif, 2012; Dzakiria, 2012; Kaur 2006). Problems related to switching from traditional face-to-face teaching styles to virtual classroom teaching that requires different communication practices such as course 
preparation and presentation peculiar to distance learning programs are significant challenges (Moore \& Kearsely, 2012). The difficulties in adopting this new role lead to instructors' mishandling or poor management of online communication tools and ineffective delivery of course contents (Rienties, Giesbers, Lygo-Baker, Ma, \& Rees, 2016).

Furthermore, according to Kaur (2006) such mishandling also leads to students' failure, lowers the morale of students to continue with the program, and occasionally leads to an intention to discontinue with the program. Angelaki (2013) argued that a lack of timely feedback on students' assignments and less active support from the tutor or instructors are reasons for early discontinuation of study. As such, investigating whether the instructors' handling or use of communication tools has connection with their pedagogical strength is highly germane in the present study.

Underutilization of communication tools like Learning Management Systems (LMS), e-mails, blogs, Facebook, and other distance learning communication platforms by instructors is very alarming in distance learning programs (Rienties et al., 2016). Many university lecturers face difficulties in using LMS to create instructional methods that truly engage students in learning (Steel, 2009). Very few distance education instructors in Malaysia truly practice some form of distance education activities timely response to forum questions, use of media for interaction etc. (Dzakiria, 2012). The inability of instructors to optimally use communication tools in teaching leads to low engagement of students' in learning activities (Kaur 2006). Surveys of student perceptions of instructors' use of LMS continue to indicate that students are concerned about the low levels of integration and quality of use of LMS in universities (Robbie, 2005). Therefore, it is necessary to investigate whether underutilization of communication media play any significant impact on distance students' cognitive engagement.

Program Pensiswazahan Guru (PPG) is designed for the in-service teachers in Malaysia. This program is conducted via distance learning in some selected Malaysia public universities. These teachers are somewhat unfamiliar with the blended distance-learning environment and the distance-learning administrators have not addressed most of their plight (MoHE 2011-2015). Due to the importance of in-service teachers, both to the Malaysian Ministry of Education and society, it is necessary to determine whether communication practices such as feedback, content, engagement, support in knowledge building, encouragement of higherorder thinking, and collaborative learning have any effect on students' engagement. Only handful of distance education instructors in Malaysia can demonstrate effective teaching to improve interaction and connectivity (Kaur 2006).

\section{Theoretical Framework}

The present study adopts Transactional Distance Learning Theory (TDLT). Transactional Distance Theory investigates the relationship between unique organization and unique teaching behaviors of instructors in distance education (Moore 2005). These teaching behaviors are classified into two clusters: dialogue and structure (Moore \& Kearsley, 2005). Dialogue connotes the interplay of words and actions and can refer to any forms of interactions between instructor and students, for example, when the instructor gives an instruction, and the student responds to it (Moore \& Kearsley, 2005). Structure, as explained by Moore (2005), consists of elements in course content. An array of research has been conducted on dialogue and structure. For instance, Murphy and (Cifuentes 2001 Saba, 2000, Lemone 2005). Cifuentes (2001) 
suggested that a balance between course structure and dialogue between instructor and students is vital for distance students' success.

Transactional distance in education usually occurs whenever students do not take interest in their learning or are not engaged in meaningful dialogue especially with their instructors (Saba, 2000). Transactional Distance Learning Theory proposes that for communication to reduce transactional distance in educational programs and increase engagement, three sets of dialogic interactions must be adequately maintained and managed (Moore \& Kearsley, 2005). These are student-student interaction, student-content interaction, and student-teacher interaction (Moore \& Kearsley, 2005). Hillman, Willis, and Gunawardena (1994) have extended the interaction to include a "student-interface" interaction. Researchers such as Chen (2001), Zhang (2003), and Lemone (2005) studied the influence of these four variables on Web-based learning. Their findings indicate the influence of dialogue and structure on students' interaction and engagement by reducing the feeling physical and psychological distance between student and instructors. They also affirm that cultural differences is a significant factor that influences transactional issues. A hypothesized model in Figure 1 summarizes the variables that guide the present study.

As suggested by Moore and Kearsley (2005), the communication practices construct is used to encapsulate the following three types of interactions: (a) student-student, (b) student-teacher and, (c) student-content. A communication tool on the other hand is composed of student-interface interaction as mentioned by authors such as Fallon, (2011), Anderson (2003), Creedon, (2007), and Dzakiria, (2012). Moore and Kearsley also suggest that "by manipulating the communication media, it is possible to increase dialogue between students and their teachers, and thus reduce transactional distance" (p. 25).

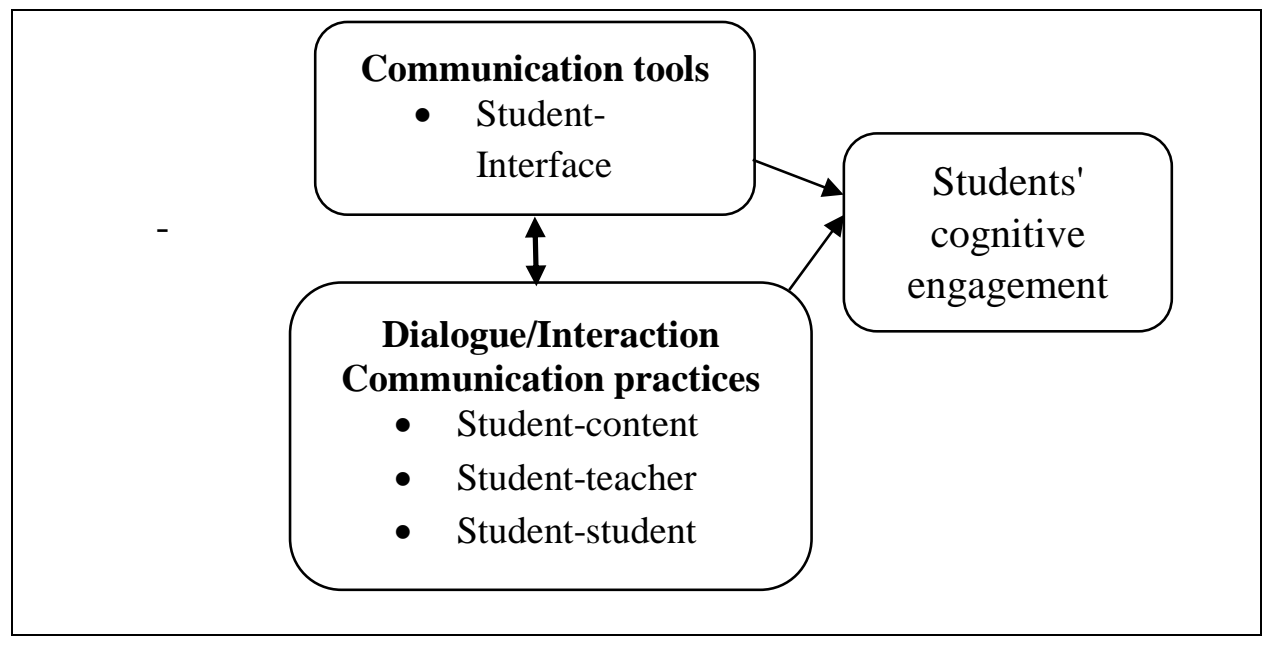

Figure 1. Hypothesized model for communication management in Distance Learning programs.

The principal point of Transactional Distance Theory as argued by its pioneer (Moore, 1989), is the centrality of the student to the educational process, of which interaction and communication play a vital role. Thus, to reduce transactional distance in teaching and learning programs, efforts must be made by instructors to manage course structure and interactions to improve students' understanding. In this study, elements of structure-student interaction, student-student interaction, student-content interaction, and 
student-teacher interaction are regarded as communication practices expected from instructors. Elements of dialogue-student-interface are classified as communication tools. This classification is premised on explanations of authors like Benson and Samarawickrema (2009) and Gorsky and Caspi (2005), who argued that distance-learning structure includes interactive activities, which are related to feedback programs, interactive course materials, and intrapersonal communication.

\section{Previous Studies}

Khan (2005) details how distance learning could be designed and managed. Khan developed an eightclustered dimensional framework that can help to create a more meaningful learning environment in distance education. The clusters included in this framework are: institutional, management, technological, pedagogical, ethical, interface design, resources support, and evaluation (Khan, 2005). Since management of activities such as communication is the core issue of the present study, the researcher included a management dimension into the conceptual framework of the current study. Management of distance learning activities described by Khan refers to the maintenance of the learning environment and the distribution of information to improve learning. These two management components are integrated to form the communication management framework of the present study. Managing communication in distance learning is therefore divided into management and development of contents (i.e. communication practice) and managing delivery (i.e. managing communication tools).

\section{Communication Practice and Communication Tools}

Distance students may be constrained by time and space, but efficient online communication may enable students to form of social ties as if they were in a traditional classroom. Hrastinski (2008) privileged online discussion over face-to-face teaching. He asserted that when students agree with their colleagues in online discussion, they form social ties, and these are important for collaborative learning (Hrastinski, 2008). Nevertheless, Hrastinski did not elaborate on the conditions that can make student participation and engagement more profoundly established in distance learning programs. It should be noted that without communication, teaching and learning cannot take place. Learning will not be produced, if communication is not well managed. Hence, the objective of teaching and learning is either not achieved or underachieved. This suggests that certain activities, elements or components are necessary for communication in teaching distance learning courses to be effective in producing learning outcomes. These communication elements or components in the context of this study are referred to as communication practices.

McCrory, Putnam, and Jansen (2008) suggest that "there are ways to make sure that students engage meaningfully with subject matter" (p. 162) and ways for "teachers... [to] monitor and guide students' thinking.... for successful online learning environments" (p. 162). Communication practices which are required within the ODL teaching pedagogy include: challenging the student to think; communicating to the student the subject of the course; providing direction and additional resources; genuinely complimenting the student's posts; following up with the student; summarizing student's comments; directing students to another post, addressing more than one student comment at a time; sharing personal/professional experiences; responding more than once per week; using two or more communication strategies; and citing material other than course material (Belcher, Hall, Kelley, \& Pressey, 
2015). Distance learning instructors must practice these twelve positive characteristics to enhance critical thinking and Interaction within threaded discussions (Belcher et al., 2015).

In her study exploring the impact that communication and social presence has on adult students in distance learning, Angelaki (2013) discovered that more than $78 \%$ of the online students surveyed did not have the opportunity to communicate with their instructors. Dzakiria (2005) commented that there are limitations to the mode of teaching and learning in distance education programs in Malaysian institutions particularly on the issue of interactivity and the use of ICT in distance education, suggesting that interactivity will lead to further engagement and active participation. Communication practice enhances the communicative bridge between university management and students (Swerling \& Thorson, 2014). Technological apparatus and administrative support for teaching and learning usually help both instructors and students to achieve their goals (Ahmad, Basha, Marzuki, Hisham, \& Sahari, 2010). Moreover, with respect to the use of communication tools in distance learning, it is highly likely that technologies which are used as media of communication would facilitate or increase practices that enhance student interaction and engagement in learning (Rajasegeran, 2012). Technology improves practices such as timely feedback from lecturers and student responses to forums, as well as improves students' interactions (Angelaki, 2013). Dzakiria (2004) suggest that student-instructor interaction that relies on communication technology to present, clarify or elaborate information supports student learning, as well as supports the processes of providing feedback, evaluation, support, and encouragement. However, Dzakiria's discussion is geared towards the use of ICT only and preparing instructors and support like provision of modules does not seem to be a concern in this discussion. This is contrary to work by Moore and Kearsley (2005), wherein caution is made not be too enthusiastic about adopting new technology, but rather to give more attention to instructors who will be using the technology. Issues like participation, engagement in learning, and active interaction of distance students is indeed a problem in Malaysia that needs attention and action by all parties involved (Dzakiria, 2012). Based on these evidences, the current study hypothesizes that:

Hypothesis 1: There is a positive correlation between communication practices and communication tools.

\section{Communication Practice and Students' Cognitive Engagement}

Effective management of course content by instructors can achieve a high level of cognitive engagement among students (Fallon, 2011; Angelaki, 2013). The previously discussed findings of both Kaur (2006) and Trevithick et al. (2004) adequately support arguments raised in this study. However, findings of both studies do not provide enough information regarding which teaching practices instructors need to integrate into their pedagogy. As such, there is a need to determine the impact of communication practices on students' engagement. In their research, Partlow and Gibbs (2003) identified different ways (called instructional practices) by which instructors can effectively deliver course material in distance learning courses. Included in the instructional practices suggested by Partlow and Gibbs are project-based learning tasks, cooperative group work, infrequent use of direct instruction, tasks that required higher-order thinking, interactivity, and student choice.

Partlow and Gibbs' (2003) research suggests a need to provide instructors with guidance regarding teaching practices that support effective delivery of course material to distance learning students, which is in line 
with the aim of this study. However, Bangert (2004) contends that this research is only an effort to inform faculty and institutions of the knowledge and expertise that are desperately needed by new course instructors. Bangert, on the other hand, proposes that institutions should focus more on quality validation of distance learning programs. The arguments of the present study are in consonance with Partlow and Gibbs' suggestions as well as with Bangert's arguments. Bangert's arguments seem to address the issue of quality and validation of instructional or communication practices (as used in this study), regardless of whether such practices result in students success

On the other hand, Partlow and Gibbs (2003) argue that evaluation of instructional practices may be counter-productive, because it may eventually jeopardize the success of the practices that are still gaining momentum. Contrary to Partlow and Gibbs' view, the argument presented in this study is that evaluation of communication practices between instructors and distance students is key in increasing student engagement and learning. Active participation and engagement in learning can only be achieved in the presence of instant messaging, teamwork, other opportunities for interaction with classmates, and course content. All these practices are expected to be designed, created or initiated by the instructors. In addition, more than 20 years ago, Chickering and Gamson (1987) identified seven guidelines for quality teaching of undergraduate in higher institution. Four of these seven guidelines dealt with interaction between the students, the instructor, and the content. As described by Lear, Ansorge, and Steckelberg (2010), instructors are individuals saddled with the responsibility of bringing a distinctive style of teaching which is developed throughout their teaching careers.

Consequently, communication practices involving clarity of languages, timely and prompt feedback, cooperation among students, pedagogical techniques, and motivation are highly encouraged for instructors (Angelaki, 2013). For students to be actively engaged in learning, instructors must seek to ensure that communication practices which facilitate dialogue (student-student, student-teacher, and student-content) such as instructional materials, course design, learning devices, clarity of language, and timely response to students' questions are well organized (Moore \& Kearsley, 2012). In relation to this argument, this study also hypothesizes that:

Hypothesis 2: Communication practices directly influence distance students' cognitive engagement.

\section{Communication Tools and Students' Engagement}

Teaching via technologies such as learning management systems (LMS), audiographic conferencing, oneway video, two-way video computer conferencing, e-mail and e-forum, and other communication media have been adopted by many higher institutions in Malaysia (Nawawi, Asmuni, \& Romiszowski, 2009). However, the challenge is on how instructors use these technologies to improve communication between and among the distance students. Integration of ICTs in distance learning programs has lifted the distance education mode of delivery from a classical first and second generation (the use of correspondence mail) to a third-generation level of operation (Shirin, Sharifah, \& Mohammed, 2014). Institutions of Higher Learning can leverage on novel digital learning infrastructure and have information and communication technologies at their hands to build global learning infrastructures (Sadat \& Rahman, 2003). 
Although technology has the potential to facilitate, enhance, and bring about effective learning, but the learning which results from the use of technology cannot be easily reproduced in other learning environments (Dzakiria, 2004). Most of the benefits of teaching and learning are intrinsic to interactivity, and it is pertinent to understand that the benefits of learning can only come via this interactive educational processes in combination with teaching tools, and not via the tools alone (Dzakiria \& Kasim, 2002). In addition, findings regarding the effect of distance learning students' perceptions of the use of technology for communication and interaction are inconclusive (Dzakiria, 2012).

More so, instructors must be able to control and adequately interpret the information and course material provided to students. Moore and Kearsley (2012) contend that what many distance-learning programs are witnessing now is simply conventional classroom instruction within conservative structures, but with the blend of new communications technology. Therefore, investigating the positive effect of communication technology on engagement of distance students is necessary. This study therefore hypothesizes that:

Hypothesis 3: Communication tools directly influence students' engagement.

\section{Method}

This study adopts a quantitative research design. Questionnaires were used to elicit responses from students on engagement and communication management (communication practices and communication tools). Quantitative research is most appropriate to support hypotheses with statistical analysis when variables are known, and the researcher is interested in examining one variable in detail or describing the relationship between variables (Neuman, 2006). Three institutions of Higher Learning was involved in this research. The sample frame was the first, second, and third cohort of in-service teachers (undergraduate) who attended lessons at three-selected university campuses through a distance learning program. The population of this present study includes PPG students from three universities. These universities are:

1. International Islamic University (IIUM)

2. Universiti Pendidikan Sultan Idris (UPSI)

3. University Sains Islam Malaysia (USIM)

This study used a systematic random sampling technique. Population for this study is 4116. The population figure was divided by the estimated samples size number of 450 to get the sampling interval. Thus, $4116 \div 450=9$, so every ninth respondent was selected. To do this, 4000 questionnaires were distributed to all students during a face-to-face learning session. One hundred and sixteen students were absent the day that the questionnaires were distributed. Therefore, only the 4000 PPG students were given the questionnaire. Prior to data collection, the students were briefed about the intent of the research. They were also informed that participation was voluntary and that there would be no repercussion for abstinence. Table 1 shows the distribution of the sample based on the three selected universities. 
Table 1

Sample Distribution Based on the University

\begin{tabular}{lcc}
\hline \multicolumn{1}{c}{ University } & $\begin{array}{c}\text { Distance students (In- } \\
\text { service teachers) } \\
\text { population (N) }\end{array}$ & $\begin{array}{c}\text { Number of samples } \\
\text { (n) }\end{array}$ \\
\hline International Islamic University Malaysia (IIUM) & 366 & 110 \\
Universiti Pendidikan Sultan Idris (UPSI) & 3,300 & 220 \\
University Sains Islam Malaysia (USIM) & 450 & 120 \\
\hline Total & 4116 & $450(10 \%)$ \\
\hline
\end{tabular}

*Note. The information on this population was obtained from office of the distance learning coordinators of IIUM, USIM, and UPSI respectively.

Four hundred and fifty teachers, which is approximately $10 \%$ of total population, were systematically selected from the population of 4000 as shown in Table 1 . The decision regarding the number of samples is based on the recommendation of Hair, Black, Babin, and Anderson (2010), who suggest that a sample size of $>=200$ respondents is deemed appropriate for the structural equation model technique (SEM). Thus, researcher put up for the ratio of 10 respondents per parameter as recommended by Hair et al. (2010). In addition, to determine the sample size of 450 from a population of 4000, the researcher adopted the margin of error or accuracy technique suggested by Sekaran and Bougie (2010). The margin of error technique helped the study to determine the sample size within the probability of error tolerated. Before employing this technique, the researcher identified two basic components: the confidence interval and the margin of error. The confidence interval was set at $95 \%$ and the margin of error was set the lowest margin of error \pm $5 \%$.

The questionnaire items used in this study were taken from previous questionnaires created by Kaur (2006) and Lammers and Gillaspy (2013). The original questionnaire consisted of 63 items. All of the dimensions of the questionnaire items from Kaur (2006) and Lammers and Gillaspy (2013) were relabeled to reflect the dimensions of the constructs currently being studied. Certain phrases were modified and included. The instrument was then subjected to tests of face validity and construct validity. Two former PPG distance learning coordinators and three $\mathrm{PhD}$ students majoring in instructional technology, educational management, and language and literacy, conducted the first round of face validity. A series of comments were received on each of the items in the questionnaire. The researcher improved the instrument based on the suggestions provided.

Content validity is an extension of face validity, which relies on an assessment of whether the proposed measure incorporates all content of a construct (Martyn \& Shuttleworth, 2009). For content validity, the instrument was sent to four experts: one professor, two associate professors (one of whom specialized in instructional technology), and one assistant professor (who specialized in measurement). This was followed by empirical evidence on the construct validity and reliability of the instrument. To test validity and reliability, a pilot test was carried out in two of the three institutions of Higher Learning selected for this study. The pilot test was conducted using distance-learning students from Universiti Pendidikan Sultan Idris (UPSI) and Institute of Education International Islamic University Malaysia (INSTED). Participants for this test included 120 PPG students: 80 participants from UPSI and 40 participants from INSTED. The 
students in the pilot test were not included in the 4000 participants sampled for the actual data. The study accomplished a three-factor solution accounting for $50.70 \%$ of the total variance explained. In other words, $50.70 \%$ of communication management model in the present study can be explained by $50.70 \%$ of the three factors. The Eigen values of three factors were in the range from 2.643 to 11.853. Based on the Composite Reliability test (CR) of each factor the factor communication practice with twenty items accounted for a very high reliability with $\mathrm{CR}$ of 0.95 , communication tools with nine items, and student engagement with eight items accounting for CR of 0.89 respectively.

\section{Data Analysis}

The data collected from the population were subjected to data management and manipulation process. No missing data were replaced. In addition, 26 samples were discarded due to extreme values (outliers). The threshold point for the outlier is based on Mahalanobis distance (D2) with $\mathrm{P}<0.001$ (Kline, 2011).

Four hundred and five (405) completed sample data from PPG distance students form the final analysis of this study. The respondents background with respect to gender include 95 males (23.5\%) and 310 females (76.5\%). This result shows that the number of female in-service teachers is more than male in-service teachers. That is, early school workforce is still dominated by women. Societal perception, status, and payment might be the contributing factors.

\section{Testing the Hypothesized Model}

The model used within this study indicates two predictors for students' cognitive engagement as well as the relationship between the predictors. This model is based on the transactional distance learning theory (TDLT). Based on the results of the factor analyses, the researcher has formulated a full-fledged latent variable of the relationships between the communication management, (explained by communication practices and communication tools) and student cognitive engagement. The researcher adopts only the hypothesized model without any competing models.

In summary, the following hypotheses need to be addressed:

$\mathrm{H}_{1}$ : Communication practices have a correlation relationship with communication tools

$\mathrm{H}_{2}$ : Communication practices directly influence distance students' engagement

$\mathrm{H}_{3}$ : Communication tools used in distance learning programs positively influence students' engagement.

With respect to general adequacy of the model, the results revealed an acceptable model fit. The relative Chi-square or Normed chi-square where the chi-square fit index divided by the degree of freedom $(\mathrm{CMIN} / d f$ ) was estimated to be 1.446 which falls below the threshold point of 3.000 (Kline, 2011), $\mathrm{p}=0.012$ (p>0.05), Root mean square error of Approximation $(\mathrm{RMSEA})=0.033$, Comparative fit index $(\mathrm{CFI})=0.985$, $\mathrm{TLI}=0.981$, Root mean square residual RMR=0.016, Goodness-of-fit index (GFI) $=0.968$ and Adjusted Goodness-of-fit index (AGFI) $=0.953$. These results thereby satisfied the general hypothesis that the structural model fit the data. Table 2 presents the summary of fit indexes of the model. Due to the fit model, 
the individual parameters are further evaluated, and three specific hypotheses of the path relationships are then estimated (see Figure 2).

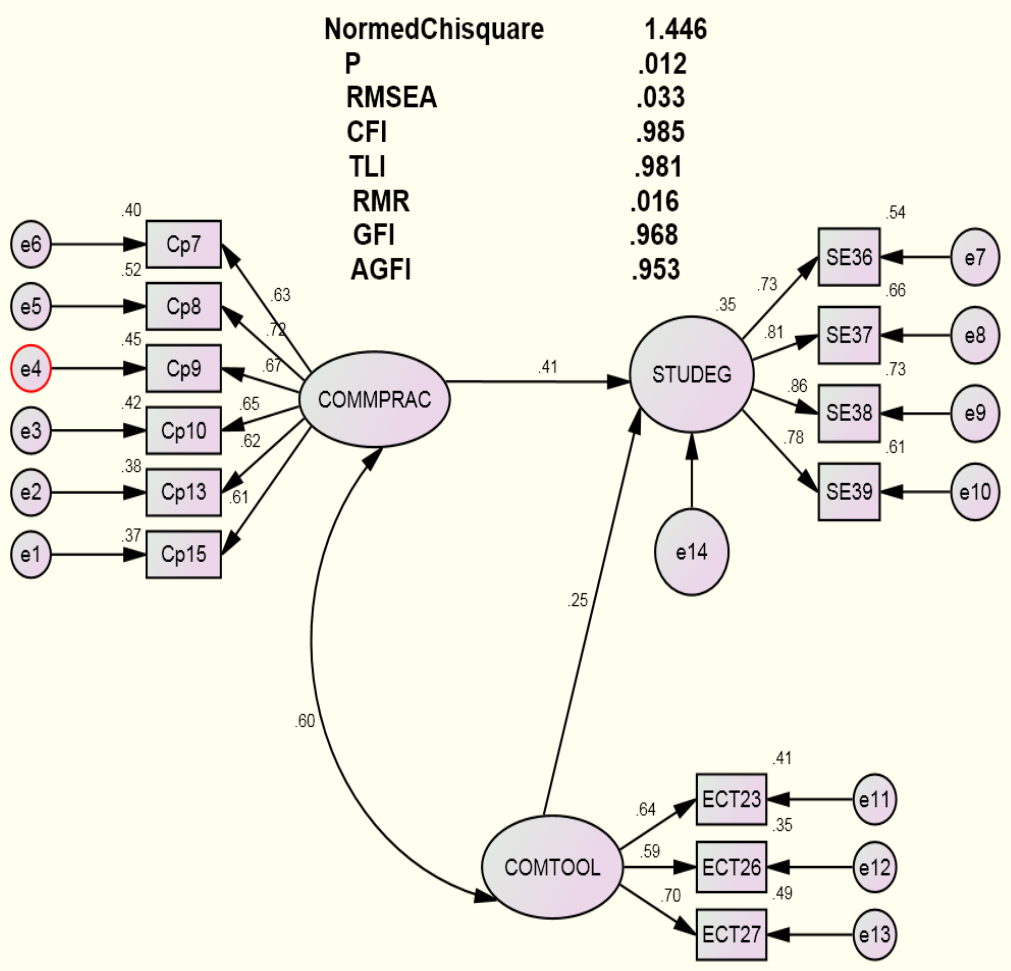

Figure 2. Hypothesized Model. COMMPRAC $=$ communication practices, $\mathrm{COMTOOL}=$ communication tools, STUDEG = student cognitive engagement.

Table 2

Fit Indexes for the Hypothesized Model

\begin{tabular}{ccc}
\hline Fit indexes & Obtained & Required value \\
\hline CMIN/DF (if N > 200) & 1.446 & $<3.0$ \\
CFI & 0.985 & 0.90 \\
RMSEA & 0.033 & 0.05 \\
GFI & 0.968 & 0.95 \\
AGFI & 0.953 & 0.95 \\
RMR & 0.016 & 0.05 \\
TLI & 0.981 & 0.90 \\
\hline
\end{tabular}


Table 3

Maximum Likelihood Parameter Estimates

\begin{tabular}{|c|c|c|c|c|c|c|}
\hline \multirow{2}{*}{\begin{tabular}{|l|} 
Parameter \\
Factor loading \\
\end{tabular}} & & $\begin{array}{l}\text { Standardized } \\
\text { parameter }\end{array}$ & \multirow[t]{2}{*}{$\begin{array}{l}\text { Critical } \\
\text { ratio } \\
\text { (C.R) }\end{array}$} & \multicolumn{2}{|c|}{$\begin{array}{l}\text { Standardized } \\
\text { error (S.E) }\end{array}$} & \multirow[t]{2}{*}{$\begin{array}{c}\text { Critical } \\
\text { ratio (C.R) }\end{array}$} \\
\hline & & \multicolumn{3}{|c|}{ Measurement error variance } & & \\
\hline $\begin{array}{l}\text { Cp15 Instructors usually } \\
\text { provoking issues during }\end{array}$ & e thought- & 0.608 & - & e1 & 0.026 & 12.538 \\
\hline $\begin{array}{l}\text { Cp13 Reference of study } \\
\text { are well organized by in }\end{array}$ & g. Web link, notes) & 0.617 & 9.796 & e2 & 0.026 & 12.466 \\
\hline $\begin{array}{l}\text { Cp1o Issue in online dis } \\
\text { students thinking }\end{array}$ & m stimulates & 0.650 & 10.240 & $\mathrm{e} 3$ & 0.027 & 12.097 \\
\hline $\begin{array}{l}\text { Cp9 Instructors/facilita } \\
\text { content of online discus }\end{array}$ & he relevancy of the & 0.670 & 10.333 & e4 & 0.027 & 11.883 \\
\hline $\begin{array}{l}\text { Cp8 Interaction betweer } \\
\text { students in my class is } \\
\text { semester }\end{array}$ & $\begin{array}{l}\text { /facilitators and } \\
\text { d throughout the }\end{array}$ & 0.724 & 10.920 & e5 & 0.023 & 11.028 \\
\hline $\begin{array}{l}\text { Cp7 Instructors/facilitat } \\
\text { instruction on topic for }\end{array}$ & nake clear & 0.634 & 9.870 & e6 & 0.026 & 12.274 \\
\hline $\begin{array}{l}\text { SE36 Discussion of cou } \\
\text { thinking }\end{array}$ & s challenges my & 0.735 & - & e7 & 0.015 & 11.871 \\
\hline $\begin{array}{l}\text { SE37 Inclusions of comp } \\
\text { discussion motivate me } \\
\text { discussions. }\end{array}$ & rstructors in & 0.813 & 15.841 & e8 & 0.015 & 10.399 \\
\hline $\begin{array}{l}\text { SE38 Discussion of cont } \\
\text { my thinking. }\end{array}$ & tructors challenges & 0.855 & $15 \cdot 971$ & e9 & 0.013 & 8.996 \\
\hline $\begin{array}{l}\text { SE39 I like to learn new } \\
\text { are clearer to me }\end{array}$ & e previous lesson & 0.783 & 15.023 & $\mathrm{e} 10$ & 0.015 & 11.151 \\
\hline $\begin{array}{l}\text { ECT23 I like posting m } \\
\text { board/chat-room/ becal }\end{array}$ & $\begin{array}{l}\text { e discussion } \\
\text { ble to use }\end{array}$ & 0.638 & - & e11 & 0.041 & 10.392 \\
\hline $\begin{array}{l}\text { ECT26 I received online } \\
\text { myLMS on time from m }\end{array}$ & $\begin{array}{l}\text { nessages from } \\
\text { and peers. }\end{array}$ & 0.595 & 8.469 & $\mathrm{e} 12$ & 0.034 & 11.203 \\
\hline $\begin{array}{l}\text { ECT27 Blog is an effecti } \\
\text { interaction }\end{array}$ & tudent-instructor & 0.698 & 9.216 & $\mathrm{e} 13$ & 0.035 & 8.960 \\
\hline Direct effects & & Distu & ince vari: & ces & & \\
\hline $\mathrm{STE}<---\mathrm{COMP}$ & 0.426 & 174 & e14 & & .136 & 7.676 \\
\hline $\begin{array}{l}\text { STE }<---\mathrm{COMTOL} \\
\text { Factor covariance a }\end{array}$ & $\begin{array}{l}0.213 \\
\text { tion }\end{array}$ & 151 & & & & \\
\hline COMP $<-->$ COMTOOL & 0.142 & & & - & .022 & 6.471 \\
\hline COMP<-->COMTOOL & 0.597 & & & & & \\
\hline
\end{tabular}

*Note. Maximum likelihood parameter estimates of standardized factor loadings, critical ratio, measurement error variances, and direct and covariance effect for structural model communication management.

Referring to Table 3, all the factor loadings were statistically significant at the 0.05 level (CR>1.96). The values were in the range of moderate loadings for item ECT26 I received online discussion messages from myLMS on time from my instructors and peers (standardized estimate was 0.595 and $\mathrm{R}^{2}=0.354$ ), to high loadings for item SE38 Discussion of content with instructors challenges my thinking (Standardized estimates was 0.855 and $\left.\mathrm{R}^{2}=0.731\right)$. All the variance of the errors were significant $(\mathrm{CR}>1.96)$. Table 4 displays the summary of the quantitative data analysis. 
Table 4

Summary of Quantitative Data Analysis and Interpretation

\begin{tabular}{|c|c|c|}
\hline Research hypothesis & Theory & Findings \\
\hline $\begin{array}{l}\text { Hypothesis } 1 \text { : Communication } \\
\text { practices positively correlate } \\
\text { with communication tools }\end{array}$ & $\begin{array}{l}\text { Transactional distance } \\
\text { learning: } \\
\text { Manipulating the communication } \\
\text { media, it is possible to increase } \\
\text { dialogue between students and } \\
\text { their teachers (Khan, 2005; Moore } \\
\text { \& Kearsley 2005). }\end{array}$ & $\begin{array}{l}\text { Finding supports the } \\
\text { hypothesis: Communication } \\
\text { practice has a significant } \\
\text { relationship with } \\
\text { communication tools. } \\
\text { Standardized correlational effect } \\
\text { of } 0.597 \text {, Critical ratio CR }>1.96\end{array}$ \\
\hline $\begin{array}{l}\text { Hypothesis 2: } \\
\text { Communication practices } \\
\text { directly influence distance } \\
\text { students' engagement }\end{array}$ & $\begin{array}{l}\text { Transactional distance } \\
\text { learning: } \\
\text { Effective use of interaction } \\
\text { between students-content, } \\
\text { student-student, student-teachers } \\
\text { (communication practices) will } \\
\text { reduce the transactional distance } \\
\text { and improve student autonomy } \\
\text { (engagement; Moore, 1989) }\end{array}$ & $\begin{array}{l}\text { Finding supports the } \\
\text { hypothesis: } \\
\text { Presence of communication and } \\
\text { interaction elements among } \\
\text { distance learning instructors } \\
\text { significantly contributed to } \\
\text { increase in cognitive } \\
\text { engagement. Standardized } \\
\text { regression weight of } 0.409 \text {, } \\
\text { CR }>1.96\end{array}$ \\
\hline $\begin{array}{l}\text { Hypothesis3: Communication } \\
\text { tools used in distance } \\
\text { learning positively influence } \\
\text { students' engagement. }\end{array}$ & $\begin{array}{l}\text { Transactional distance } \\
\text { learning: } \\
\text { Communication tools that promote } \\
\text { student-interface interactions } \\
\text { increase students' engagement in } \\
\text { learning (Anderson 2003; } \\
\text { Creedon, 2007; Dzakira, 2012). }\end{array}$ & $\begin{array}{l}\text { Finding supports the } \\
\text { hypothesis: } \\
\text { Efficient use of communication } \\
\text { tools such as private } e \text {-mails, } \\
\text { online discussion messages } \\
\text { from myLMS, creation and use } \\
\text { of Blog, positively influences } \\
\text { students' cognitive engagement. } \\
\text { Standardized regression weight } \\
\text { of } 0.213(\mathrm{CR}>1.96)\end{array}$ \\
\hline
\end{tabular}

\section{Discussion}

\section{Communication Practice Positively Correlates With Communication Tools}

The results in Table 3 reveal that communication practice has a significant relationship with communication tools with a standardized correlational effect of 0.597. Thus, it can be concluded that 59.7\% of the number of times the respondents (the in-service teachers) experience communication practices (presentation of interesting e-forum discussions and well-organized reference of study materials) in distance learning programs, is attributable to efficient use of communication tools such as private e-mails, myLMS, and use of Blog and Facebook by the instructors. The remaining number of times (40.3\%) inservice teachers experience good communication practices, is due to other reasons. Therefore, the more the instructors in distance learning use the features available in myLMS, blogs, and private e-mails in teaching, the greater the students experience efficient communication practices. This relationship has shown that as distance students (in-service teachers) experience the use of diverse features in communication medium 
such LMS, e-mail, and Facebook (communication tools), the more they interact with their, learning material, colleagues, and instructor. Wahlstedt and Honkaranta (2007) support this as they asserted that communication tools like LMS, e-mails, Facebook etcetera, have provided tremendous prospect for students' interaction as well as prompt feedback from tutors.

\section{Communication Practice Positively Influenced Student Cognitive Engagement}

Table 4 reveals that application of communication practices such as presentation of thought-provoking issues during discussion, justifying the relevancy of the content of online discussion, well-managed connectivity and rapport have an effect on student cognitive engagement in challenging discussion with peers, motivation to response in other discussions and willingness to learn new things. The strength of this causal relationship is relatively strong with standardized direct effect of 0.409 (CR>1.96). These results indicate that communication practices by DL instructors predicted students' effort to engage in learning, which in turn determined their learning outcomes at the end of PPG distance learning programs. In other words, students whose instructors provide communication practices measured by course content, learning material, and feedback had higher levels of cognitive engagement, and spent effort in learning, and therefore higher levels of performance in tests taken at the end of courses. In tandem with Burgess (2006), interaction and teamwork among students and cooperation between students and instructors are practices that are necessary for students' creative and critical thinking in a genuine context.

In addition, this study supports research by McGivney (2004) and Khan (2005) who suggest that managing learning resources such as course content and presentation, together with an interactive students' group, promotes higher thinking and self-directed distance learning students. On the other hand, our results contradicted studies by Coates (2006), Trowlers (2010), and Fredrick et al. (2004), within which learning environment and individual learning attitude are the determinants of how engaged students are. In our study, the students' cognitive engagement was explained by only $35 \%$ of its predictors, namely communication practices and communication tools. However, other factors such as learning environment structure and process and students' attitude towards learning may provide more influence on cognitive engagement among distance students. Further research on these factors is therefore needed.

\section{Communication Tools Positively Influenced Students' Engagement}

Table 4 shows that the communication tools significantly influenced students' engagement with a standardized direct effect of $0.213(\mathrm{CR}>1.96)$. This estimate indicates that the efficient use of communication tools such as private e-mails, e-forum discussion and myLMS, by distance learning instructors contributes to students' engagement in challenging discussion with peers, response in other discussions, challenges thinking contents. This indicates that students whose instructors optimally utilize the feature in communication tools like LMS were more interested in learning. A study conducted by $\mathrm{Yu}$ and $\mathrm{Yu}$ (2002) confirmed that e-mail is viable in promoting students' cognitive growth and engagement especially in distance learning. E-mail has characteristics that influence its suitability for learning purposes (Bouhnik \& Deshen, 2014; Calvo, Arbiol, \& Iglesias, 2014). The use of LMS and the use of other social interactive features such as e-mail and Facebook usually initiate class discussion among students and instructors (Almrashdeh et al., 2010). However, the direct relationship between communication tools and students' cognitive engagement appears not to be very high as compared to communication practices. 
In summary, the hypothesized model has provided a reasonable explanation of the structural model of communication management (communication practices and communication tools) and students' cognitive engagement employed in the present study. The model was explained by two exogenous variables (communication practices and communication tools) and one endogenous variable (students' engagement). The overall observed variables that defined the respective factors are 13 indicators, 13 error variance and 1 residual.

Furthermore, findings from the hypothesized structural model have contributed to the implications for modeling of communication and interaction in distance learning by others (Anderson, 2003; Angelaki, 2013; Dzakiria, 2012; Moore, 1993) and cognitive engagement by Trowler (2010). The model has further expanded the theory of transactional distance learning by including communication tools (studentinterface interaction) interaction in the context of communication management in distance learning.

\section{Conclusion}

Communication practices and communication tools are significantly related to students' engagement. However, the current state of use of communication tools in ODL programs in Malaysian public Higher Learning institutions surveyed is not efficient enough to allow for a great deal of content control and interaction between teacher and students. Communication practices are the strongest predictor that significantly contribute to student engagement in distance education settings. Nevertheless, insufficient and inefficient use of communication tools like LMS characterize the management of communication in the delivery course content to distance students. This indicates that distance-learning instructors are underutilizing the communication tools, which has led to low student engagement in learning and low management of communication in distance learning in general.

\section{Implications of the Study}

\section{Theoretical Implication}

This study has extended literature in Transactional Distance Theory, communication management, and student engagement. Previous findings of the Transactional Distance Learning Theory indicated that the basic interaction in distance learning revolved around three interactions: student-student, student-content, and students-teacher (Moore, 2005). However, the findings of the present study have shown that interaction in transactional distance theory must also include communication tools (students-interface) interaction.

\section{Implications to Education}

This study has pointed out the need for university management to investigate patterns of communication and interaction between students and instructors in distance learning programs. The need for an efficient use of communication media is imperative because it allows prompt and regular feedback (communication 
practices). There is also a need for thought-challenging discussions and willingness to learn new things (cognitive engagement). An ideal distance learning instructor should be able to organize, manipulate, and present lessons to produce creative and self-regulated students. Despite the existing learning materials and Learning Management System (LMS) in the three universities observed, self-dependent learning ability of the PPG students in the institutions needs to be further enhanced. Thus, administrators should increase training to improve the skills and competence of the instructors to make learning be closer, challenging, and interesting to students. This helps students become more involved in the learning process. 


\section{References}

Ahmad, T. B. T., Basha, K. M., Marzuki, A. M., Hisham, N. A., \& Sahari, M. (2010). Faculty's acceptance of computer-based technology: Cross-validation of an extended model. Australasian Journal of Educational Technology, 26(2), 268-279. http://www.ascilite.org.au/ajet/ajet26/ahmad.html

Almarashdeh, I., Nur Fazidah, E., Noraidah, S., \& Nor Azan, M. Z. (2013). Development of an interactive learning management system for Malaysian distance learning institutions Middle-East. Journal of Scientific Research, 14(11).

Allen, I. E., \& Seaman, J. (2013). Conflicted: Faculty and online education, 2012. Babson Park, MA:

Babson Survey Research Group. Retrieved http://files.eric.ed.gov/fulltext/ED535214.pdf

Anderson, T. (2003a). Getting the mix right again: An updated and theoretical rationale for interaction. International Review of Research in Open and Distance Learning, 4(2). Retrieved from http://www.irrodl.org/index.php/irrodl/article/view/149/230

Angelaki, C. (2013). Communication and social presence: The impact on adult students' emotions in distance learning. Journal of the Theoretical Humanities, 18(1), 78-93.

Bangert, A. W. (2004). The seven principles of good practice: a framework for evaluating online teaching. The Internet and Higher Education, 7(3), 217-232. Retrieved from http://dx.doi.org/10.1016/j.iheduc.2004.06.003

Bahroom, R., \& Abdol Latif, L. (2012). Open and distance learning as the key driver of lifelong learning. Proceeding Malaysia Ministry of Higher Education Seminar on Life Long Learning Seminar: PWTT, Kuala Lumpur, 22-23 September 2012.

Belcher, A. R., Hall, B. M., Kelley, K., \& Pressey, K. L. (2015). An analysis of faculty promotion of critical thinking and peer interaction within threaded discussions. Online Learning, 19(4).

Benson, R., \& Samarawickrema, G. (2009). Addressing the context of e-learning: using transactional distance theory to inform design Distance Education, 30(1) 5-21. doi: ttp://dx.doi.org/10.1080/01587910902845972

Bouhnik, D., \& Deshen, M. (2014). WhatsApp goes to school: Mobile instant messaging between teachers and students. Journal of Information Technology Education: Research, 13, 217-231. Retrieved from http://www.jite.org/documents/Vol13/JITEv13ResearchP217-231Bouhniko601.pdf

Burgess, J. (2006). Transactional distance theory and student satisfaction. (Doctorate dissertation, The University of West Florida). Retrieved from http://uwf.edu/vburgess/Final Dissertation.pdf

Calvo, R., Arbiol, A., \& Iglesias, A. (2014). Are all chats suitable for learning purposes? A study of the required characteristics. Procedia Computer Science, 27, 251-260. 
Chen, Y.-J. (2001). Dimensions of transactional distance in the World Wide Web learning environment: A factor analysis. British Journal of Educational Technology, 32(4). 459-470. http://dx.doi.org/10.1111/1467-8535.00213

Chickering, A. W., \& Gamson, Z. F. (1987). Seven principles of good practice in undergraduate education. AAHE Bulletin, 39(7), 3-7.

Coates, H. (2006). Student engagement in campus-based and online education. London: Routledge. Retrieved from http://www.cqu.eblib.com.ezproxy.cqu.edu.au/EBLWeb/patron/

Creedon, S. (2007). Preparing nurses on-line to work off-line: Experiences gained from teaching final year undergraduate nursing students in Ireland. Online Journal of Nursing Informatics (OJNI), 11(1). Retrieved from http://ojni.org/11_1/creedon.htm

Dzakiria, H. (2004). Technology does not always teach distance students, but effective distance teachers do. Journal of Open and Distance Learning, 1(1), 1823-1144.

Dzakiria, H. (2012). Illuminating the importance of learning interaction to open distance learning (ODL) success: A qualitative perspectives of adult students in Perlis, Malaysia. The Journal of Open Distance Learning, 16(59), 111-125.

Dzakiria, H., \& Kasim, A. (2002). ICT acceptance and enthusiasm: A case study of University Utara Malaysia Students, Malaysian. Journal of Educational Technology, 2(2), 67-76.

Fallon, G. (2011). Making the connection: Moore's theory of transactional distance and its relevance to the use of a virtual classroom in postgraduate online teacher education. Journal of Research on Technology in Education, 43(3), 187-209.

Gorsky, P., \& Caspi, A. (2005). A critical analysis of transactional distance theory. The Quarterly Review of Distance Education, 6(1), 1-11.

Guffey, M. E. (2008). Business communication: Process \& product. Mason, OH: Southwestern, Cengage Learning.

Hair, J. F., Black, W. C., Babin, B. J., \& Anderson, R. E. (2010). Multivariate data analysis (7th ed.). New York: Pearson Prentice Hall.

Hillman, D. C., Willis, D. J., \& Gunawardena, C. N. (1994). Student interface interaction in distance education: An extension of contemporary models and strategies for practitioners. The American Journal of Distance Education, 8(2), 3-42.

Hrastinski, S. (2008). The potential of synchronous communication to enhance participation in online discussions: A case study of two e-learning courses. Journal of Information \& Management, 45, 499-506. 
Kaur, A. (2006). E-learning challenges as perceived by communities of practice: Open University

Malaysia's experiences. Asian Association of Open University (AAOU) Journal, 2(1), 51-65.

Khan, B. H. (2005). Managing e-learning strategies: Design, delivery, implementation, and evaluation. Information Science Publishing (an imprint of idea group), Covent Garden, London.

Kline, R. B. (2011). Principles and practice of structural equation modeling (3rd ed.). New York, NY: The Guildford Press.

Lammers, W. J., \& Gillaspy J. A. Jr. (2013). Brief measure of student instructor rapport predicts student success in online courses. International Journal for the Scholarship of Teaching and Learning, $7(2)$.

Lear, J. L., Ansorge, C., \& Steckelberg, A. (2010). Interactivity / community process. Model for the Online Education Environment, 6(1), 71-77.

Lemone, K. A. (2005). Analyzing Cultural Influences on E-Learning Transactional Issues. Proceeding of E-Learn: World Conference on E-Learning in Corporate, Government, Healthcare, and Higher Education (pp. 2637-2644). Vancouver, Canada.

Lentell, H. (2003). The importance of the tutor in open and distance learning. In A. Tait \& R. Mills (Eds.), Rethinking student support in distance education change and continuity in an international context. London, UK: Routledge Falmer.

Malaysia Ministry of Higher Education.(2015). Blueprint 2015-2025 executive summary Kementerian Pendidikan. Putrajaya, Malaysia. Retrieved from www.moe.gov.my

Shuttleworth, M. (2009). Content validity. Retrieved from https://explorable.com/content-validity

McCrory, R., Putnam, R., \& Jansen, A.(2008). Interaction in online courses for teacher education: Subject matter and pedagogy. Journal of Technology and Teacher Education, 16(2), 155-801.

McGivney, R. (2004). Technologies of online learning (E-learning). In T. Anderson \& F. Elloumi (Eds.), Theory and practice of online learning. Athabasca, Canada: Athabasca University.

Mei, L., Su L.W., Ahmad, F. A., \& Rosnaini, M. (2017). Teachers' perceptions of e-learning in Malaysian secondary schools. Malaysian Online Journal of Educational Technology, 5(2) 20-33.

Ministry of Higher Education.(2010). Report on the Implementation of the National Higher Education Strategic Plan: Planning and research division. Putrajaya, Malaysia. Retrieved from www.moe.gov.my

Ministry of High Education. (2015). Graduation determination review: Employment and status of employment. Putrajaya, Malaysia. Retrieved from www.moe.gov.my 
Moore, M. G. (1989). Editorial: Three types of interaction. The American Journal of Distance Education, $3(2), 1-6$.

Moore, M. G. (1993). Theory of transactional distance. In D. Keegan (Ed.), Theoretical principles of distance education (pp. 22-38). London, UK: Routledge.

Moore, M. G., \& Kearsley, G. (2012). Distance education: A systematic view of online learning (3rd ed.). Belmont, VA: Wadsworth Cengage Learning.

Moore, M.G., \& Kearsley, G. (2005). Distance education: A systems view. New York: Wadsworth.

Murphy, K. L., \& Cifuentes, L. (2001). Using Web tools, collaborating, and learning online. Distance Education: An International Journal, 22(2), 285-305.

Neumann, M. S., \& Yu. (2003). Differences between traditional and distance education academic performances: A meta-analytic approach. The International Review of Research in Open and Distance Learning, 4(2), 297-321.

Noraini, C. H. (2010). Economic literacy among Malaysian students and student teachers: Education system in Malaysia. Saarbrücken, Germany: LAP Lambert Academic Publishing.

Partlow, K. M., \& Gibbs, W. J. (2003). Indicators of constructivist principles in Internet-based courses. Journal of Computing in Higher Education, 14(2), 68-97.

Rajasegeran, R. (2012). Blended discrete trial clinical method to enhance performance in elearning mathematics courses (B7). Conference proceeding of Smart innovations in Education and lifelong learning. Muang Thong Thani, Nonthaburi, Thailand

Rienties, B., Giesbers, B., Lygo-Baker, S., Ma, H. W. S., \& Rees, R. (2016). Why some teachers easily learn to use a new virtual learning environment: a technology acceptance perspective. Interactive Learning Environments, 24(3), 539-552.

Robbie, D. (2005). Students use and experiences of Bb at Swinburne: A longitudinal study 2001-2005. Paper presented at the Blackboard Asia Pacific Users Conference, Melbourne.

Saba, F. (2000). Research in distance education: A status report. International Review of Research in Open and Distance Learning, 1(1). Retrieved from http://www.irrodl.org/index.php/irrodl/issue/view/4/337

Sadat, A. \& Rahman K. M. R. (2003 12-14 November). Prospect of email communication as an educational tool for distance education in Bangladesh theme. Paper presented at Provision for youth and young children Annual Conference, Thailand.

Sa'don, N. F. B., Dahlan, H. B. M., \& Zainal, H. B. (2013, November). Derivation for design of virtual learning environment (VLE) framework for Malaysian schools. Conference proceeding of 
Effect of Communication Management on Distance Learners' Cognitive Engagement in Malaysian Institutions of Higher Learning Kayode

International Conference on Research and Innovation in Information Systems (ICRIIS; pp. 570575). IEEE.

Sekaran, U., \& Bougie R. (2010). Research methods for business (5th ed.). Haddington, East Lothian: Scotprint.

Shirin, H.B., Sharifah Sariah Syed, H., \& Mohammad, S. I. (2014). Interaction in e-learning environment: Does it fulfill with Islamic teaching? Malaysian Online Journal of Educational Management 2(4), 36-52.

Singh, H. (2003). Building effective blended learning programs. Educational Technology, 44(1), 51-54.

Steel, C. (2009). Reconciling university teacher beliefs to create learning designs for LMS environments. Australasian Journal of Educational Technology, 25(3), 399-420.

Swerling, J., \& Thorson, K. (2014). The role and status of communication practice in the USA and Europe. Journal of Communication Management, 18(1), 2-15.

Taylor, D. (2006). Issues , trends , and challenges in distance education: An international perspective, eJournal of Instructional Science and Technology, 4(1), 41-25.

Trevithick, P., Richards, S., Ruch, G., Moss, B., Lines, L., \& Manor, O. (2004). Teaching and learning communication skills in social work education. London, United Kingdom: Social Care Institute for Excellence (SCIE).

Trowler, V., \& Trowler, P. (2010) Student engagement evidence summary. York: Higher Education Academy. Available at http://www.heacademy.ac.uk/assets/documents/studentengagement/StudentEngagementEvide nceSummary.pdf

Wahlstedt, A., \& Honkaranta, A. (2007). Bridging the gap between advanced distributed teaching and the use of learning management systems in the university context. Proceedings of the Seventh IEEE International Conference on Advanced Learning Technologies. Proceedings of a meeting held 18-20 July 2007, Niigata, Japan.

Yu, F. Y., \& Yu, H. J. (2002). Incorporating e-mail into the learning process: its impact on student academic achievement and attitudes. Computers and Education Journal, 38(117). 117-126.

Zhang, A. (2003). Transactional distance in web-based college learning environments: Toward measurement and theory construction (Unpublished doctoral dissertation). Virginia Commonwealth University, Richmond. 
Effect of Communication Management on Distance Learners' Cognitive Engagement in Malaysian Institutions of Higher Learning Kayode

Athabasca

University

(c) 